\title{
Marine (sea) Familiarity Index and Its Influence to National Image*
}

\author{
Dong-Gen Rui ${ }^{1}$, Yong-Ki Jung ${ }^{2}$, Chun-Su Lee ${ }^{3}$ \\ I First Author Professor, School of International Area Studies, Pukyong National University, Busan, Korea \\ E-mail: buuli@pknu.ac.kr
}

2 Second Author Researcher, Agency for Defense Development, Seoul, Korea

E-mail: bravejung@kaist.ac.kr

3 Corresponding Author Professor, Department of International Commerce, Pukyong National University, Busan, Korea.

E-mail: leecs@pknu.ac.kr

Received: July 30, 2019. Revised: August 25, 2019. Accepted: September 5, 2019.

\begin{abstract}
Purposes - This study discusses various aspects of familiarity with the sea and how familiarity with the sea is perceived. This study also summarizes the literature on the factors of previous researches that affect the formation or decision of national image.

Research design and methodology - Sea familiarity index was derived from the results of recognition of free association with the sea, friendliness with the sea, association of the sea with life, interest to the sea, Korea's representative marine regions, and sea related emotionalism. The familiarity with the sea (ocean) perceived by foreign visitors or foreigners in the future will be helpful in deriving a comparative research.

Results - This study has identified the marine tourism resources, marine ecology, and the cognitive and emotional situations consumers feel that should be developed practically. If a continuous time series research is conducted in the future through these, it will be a chance to provide a basis for consumers' dynamic awareness.

Conclusions - Through this study, it is pointed out that the research utilizing the sea and ocean to form national image highly suggested an opportunity to add and utilize new variables academically. This study on the perspective of the formation of national image suggests a new approach to add and utilize new variables to future research using the sea and ocean.
\end{abstract}

Keywords: Marine image, Korean image, Cultural contents, Marine familiarity index, Development strategy

JEL Classification Code: L8, M3, Z1.

\footnotetext{
* This paper based on using the Marine Familiarity Index data of Pukyong's 2018 report on Marine Index of the Pukyong National University CORE Project Group. This study presented at the Fall Conference of the Korea Research Association of International Commerce (2019)
} 


\section{Introduction}

Three sides of South Korea are surrounded by the sea. However, the image of one of the maritime powers has not been stood out yet. In order to raise the South Korea's image as a maritime power under various unfavorable factors such as bankruptcy of Hanjin Shipping, it is necessary to raise the marine familiarity. It is also necessary to prepare a plan to raise national image to a higher level through familiarity with the sea. National image is formed by various factors. One of the most important thing among them is familiarity. This familiarity is formed by several factors. In this study, this study discusses various levels of the awareness of familiarity with the sea and how familiarity with the sea is related to national image.

Lee (2015) found that South African consumers' perception of national image on South Korea has a positive influence on purchase intention. The study of Zhang, Kim and Lee (2015) conducted a research where Korean cultural products and the image of South Korea affect consumers' medical tourism intention. Regarding national image, Chang (2013) distinguishes between the general image of a country and the product image of a country and distinguishes which factor generally influences national image formation. In particular, they divided the general national image into cognitive image, emotional image, and normative image and explained that each image influences national image. Yi and Lee (2014) divided national image into economic image, relationship image and image of the people and studied the dimension influencing the national product image. Therefore, it can be said that the marine (sea) familiarity can also belong to the cognitive, emotional, and relational image. In particular, it can play the role as one of the elements of the general national image and the components of the product country image.

This study was conducted to survey the 1,001 adults in South Korea to use it as marine familiarity awareness data. This familiarity survey was conducted from December 15, 2017 to December 27, 2017, based on 1:1 interviews. In the contents of the familiarity with the sea (ocean), marine (sea) familiarity index was measured based on the familiarity with the sea, the extent to which the sea affects life, and the degree of positive emotions related to the sea. In detail, this research explains the results of the recognition of free association with the sea, the degree of familiarity with the sea, the relationship between the sea and life, the interest in the sea, the marine regions representative of South Korea, and the sea related emotionalism. This study investigates the familiarity with the sea that South Koreans recognize first, mutually compares familiarity items of ocean (sea) that future foreign visitors or foreigners recognize and presents a new point of view for checking the difference among them. Also this study suggested ways to improve national image by utilizing the familiarity with the sea (ocean).

\section{Literature Review}

\subsection{Studies on Determinants of National Image}

In general, national image means the overall impression consumers have about a particular country (Roth \& Romeo, 1992). This is the perception or stereotype of consumers about a specific country combined by various attributes of the economic, political, social and cultural environment. Martin and Eroglu (1993) defined national image as a total of beliefs that provide explanatory and inferential information and clues that consumers have about a specific country. It also distinguishes between a macro image of national image and a microscopic image of national image. Recent studies on national images have found that national image is composed of various elements including not only the economic, political, and cultural dimensions of the nation itself but also the image of the people of the nation (Ahn, 2005). Choi (2013) derived an integrated implication by analyzing cultural marketing cases of Korea's export companies using Hallyu (Korean Wave). In addition, he presented a concrete plan for leveraging culture for marketing when Korean companies pioneer the overseas market. In addition, Bae and Kim (2011) argue that the more abundant the image of cultural contents products, the more favorable attitudes toward Korean Wave.

The spread of Korean Wave contributes to the national brand rise and increase of recognition level about South Korea. In addition, although it enhances cultural intimacy to act as a lubricant for business communication with consumers, it has been analyzed that there is relatively small direct effect on exporting companies in the manufacturing sector except for some consumer goods such as cosmetics and foods (Choi, 2013). In addition, he argues that it is necessary to make efforts to approach the foreign market using Korean Wave as a way of using culture. The direction of this access strategy is to identify the direct relation of the product with Korean wave contents or Korean wave stars and the direct relation with the Korean lifestyle. Chang (2013) analyzed the influence 
to the intention to use the service product centered on Chinese consumers through the correlation between the national image factors as an external clue and attitude, satisfaction and re-use intention.

Table 1: Studies and Formative Factors Related to National Image

\begin{tabular}{|c|c|}
\hline Researcher & National Image Formative Factors \\
\hline Kelman (1965) & $\begin{array}{l}\text { Degree of international travel, international events, contact with foreigners, } \\
\text { social/psychological/cultural similarity }\end{array}$ \\
\hline Bojanic (1991) & $\begin{array}{l}\text { Beautiful beach, accommodation, residential amenities, beautiful buildings, boring places, } \\
\text { national wealth level, road condition, unusual food, dishonest residents, value of American } \\
\text { currency, safety, interesting cities, discount shopping, night activities, number of European } \\
\text { tourists, language communication, historical artifacts, favorability to Americans }\end{array}$ \\
\hline Fontayne (1991) & $\begin{array}{l}\text { Accommodation, culture, location, safety, cleanliness, airline, airport service, food, shopping, } \\
\text { public transport, festival, climate, price }\end{array}$ \\
\hline $\begin{array}{c}\text { Echtner and } \\
\text { Ritchie (1991) }\end{array}$ & $\begin{array}{l}\text { Various activities and attractions, economic factors, cultural contact, nature experience, } \\
\text { recreation environment, comfort, travel convenience, language communication possibility }\end{array}$ \\
\hline $\begin{array}{c}\text { Martin and } \\
\text { Eroglu (1993) }\end{array}$ & $\begin{array}{l}\text { The level of quality of life, economic growth, economic stability, agricultural self- } \\
\text { sufficiency, democratization level, industrialization level, mass production capacity, civil } \\
\text { government, labor cost, illiteracy rate, level of market liberalization, welfare level, product } \\
\text { quality, technological research level }\end{array}$ \\
\hline Hang (1993) & $\begin{array}{l}\text { Degree of cultural development, degree of industrialization, history and tradition, social } \\
\text { stability, degree of richness, degree of democratization, national education level, diligence of } \\
\text { the people }\end{array}$ \\
\hline Eom (1998) & $\begin{array}{c}\text { Travel convenience, exotic experience, travel cost, friendliness, cultural contact, urban } \\
\text { experience }\end{array}$ \\
\hline Kim (1999) & $\begin{array}{l}\text { History and tradition, culture and arts, kindness and courtesy, natural scenery and climate, } \\
\text { political stability, education level, price, degree of democracy, economic growth, crime } \\
\text { situation, public order, national favorability }\end{array}$ \\
\hline $\begin{array}{l}\text { Lee, Yang, and } \\
\text { Lee (2009) }\end{array}$ & Private-level activities, government-level activities, enterprise-level activities \\
\hline
\end{tabular}

Note: Modified from Lee (2006)

In $<$ Table $1>$, this study identified national image related studies and the factors of national image related to ocean and the sea in the study of Lee (2006). The main studies related to national image are divided into two streams related to the general national image and the general product country image (Lee \& Ganesh, 1999). The first is the research flow in which the overall cognitive dimension for a specific country is related to images, focusing on the image of the general national image. The second is the flow of research conducted in relation to the national image measurement of overall quality perception of products produced in a country centering on the general product country image. The general product country image refers to the image of country's products or the overall image of consumers that consumers have about country's products (Parameswaran \& Pisharodi, 1994).

Lee, Yang and Lee (2009) looked at the components of national image with economic factors and non-economic factors. In addition, for the factors influencing national image, they presented the variables that can explain each activity for the analysis using the variables of government, enterprise, and private dimension activities. First of all, the number of years of diplomatic relations by country and the number of government affiliated institutions were measured in terms of government activities. In terms of enterprise activities, they measured the export amount to each country and the amount of foreign direct investment. Lastly, the number of foreign workers by country, the number of South Koreans who left for travel and religious activities, and the cultural products (number of exported films) were used as influence variables in private sector activities. 


\subsection{Sea and Ocean Related Studies}

Studies on ocean and the sea have been studied in terms of marine culture and tourism and have researched various aspects such as marine logistics and ship. The sea, unlike ocean, is a more romantic and has sensuous feeling. However, ocean has logistics and more business-like feeling. However, apart from the emotions and concepts of the sea and ocean, related studies often use the two terminologies by a mix.

The following studies can be suggested as precedent studies of existing studies related to ocean. Kim, Kim and Lee (2018) argue that the sea, which makes up 70\% of the Earth's surface, and its resources are the common resources of mankind and conducted studies to prevent marine ecosystem destruction and industrial damage by ballaster water. Kim (2018) considered that discussions on the role of the Korea Maritime Advancement Corporation, which was initially established by the Korea Maritime Advancement Corporation, focused mainly on differentiated shipping finance support and support for existing policies. In addition, he focused on the promotion of cooperation between ship owners and shippers and carried out a suggestive study on the role of Korea Maritime Advancement Corporation.

Hyun, Ye and Lee (2019) presented implications for the sustainable development of the marine culture in Korea and an empirical model for the study and analysis of the marine culture in the future through the actual data of a report on marine culture in Korea. In addition, they defined that marine culture is a phenomenon that affects various values and attitudes in the temporal category as a whole cultural phenomenon including marine culture and arts, marine history, marine folklore, marine leisure sports, marine tourism, and marine environment.

Kim, Kim and Kim (2014) conducted a study to suggest ways to revitalize marine tourism, reflecting the characteristics of marine tourism users, focusing on gender and age. The study of Lee and Kang (2017) argued that for the development of differentiated urban brands, focusing on maritime cities, it is necessary to find out stories about various marine tourism resources and to develop related contents. The study of Ha (2018) argues that marine tourism festivals should include education contents centering on marine culture and environment in order to make a sustainable marine tourism plan.

Overseas examples of marine, port and waterfront development are diverse. For example, many countries, such as London Docklands in the UK, Hamburg Hafen City in Germany, Yokohama MM21 in Japan, Darling port in Sydney Australia, and Baltimore Inner port in the US, attempted the development of marine ports and spaces. South Korea is also developing ports and waterfront spaces nationwide based on Article 51 of Port Act (establishment of basic plan for redevelopment of ports) and Article 50 of the Enforcement Decree (notification of basic plan for port redevelopment, etc.). Especially, South Korea is establishing the hubs of tourism and leisure activities by integrating marine leisure and tourism facilities, marine transportation and tourism support facilities as marine tourism and leisure bases such as Incheon Port (Yeongjongdo Island dumping site), Donghae and Mukho Port (Stages 1, 2 , and 3 of Muhko area), Yeosu Port (new port), Mokpo Port South Port (dumping site), Guryongpo Port (dumping site) Busan Port (North Port Yongho Pier), Jeju Port (inner port) and Seogwipo Port. In addition, two ports, Kunsan Port (inner port) and Mokpo Port (inner port), were designated as historical and cultural hubs that have the theme of the modern cultural street, exhibition, cultural facilities, port related modern industrial heritage as hubs for port opening history and culture ( $\mathrm{Ji}, 2018)$.

Through the previous studies on national image and ocean, it can be seen that national image is influenced by the degree of familiarity and various cultural phenomena and realities such as ocean. Therefore, this study should precede the investigation and analysis of the perception of the Korean people based on their familiarity with the sea to enhance familiarity and develop marine culture. Based on this, it is necessary to identify the perception of Korean maritime familiarity in the first place with the idea that what truly Korean is global.

\section{Marine (Sea) Familiarity Awareness Survey}

\subsection{Marine (Sea) Awareness Survey}

\subsubsection{The Sea of South Korea - Free Association}

In South Korea's free association with the sea, $8.1 \%$ of respondents reminded "blue", followed by "wave" (7.8\%) and "seafood" (3.9\%). 
Table 2: Free Association about the Sea of South Korea for Each Characteristic of Respondents

\begin{tabular}{|c|c|c|c|c|c|c|c|c|}
\hline \multicolumn{9}{|c|}{ (Unit: No. of people, ${ }^{\circ}$} \\
\hline Category & $\begin{array}{l}\text { No. of } \\
\text { Cases }\end{array}$ & $\%$ & Category & $\begin{array}{l}\text { No. of } \\
\text { Cases }\end{array}$ & $\%$ & Category & $\begin{array}{l}\text { No. of } \\
\text { Cases }\end{array}$ & $\%$ \\
\hline Total & $(1,001)$ & 100.0 & Seashore & (8) & 0.8 & $\begin{array}{c}\text { Hallyeosudo Marine } \\
\text { National Park }\end{array}$ & (3) & 0.3 \\
\hline Blue & $(81)$ & 8.1 & Contamination & $(8)$ & 0.8 & Scary & $(3)$ & 0.3 \\
\hline Wave & $(78)$ & 7.8 & Horizon & $(8)$ & 0.8 & Shark & (3) & 0.3 \\
\hline Seafood & $(39)$ & 3.9 & Beautiful & $(7)$ & 0.7 & Sokcho & (3) & 0.3 \\
\hline East Coast & (38) & 3.8 & $\begin{array}{c}\text { Three sides are } \\
\text { surrounded by the sea. }\end{array}$ & (7) & 0.7 & Oil spill in Taean & (3) & 0.3 \\
\hline Beach & $(38)$ & 3.8 & Big heart / wide mind & (7) & 0.7 & Hometown & $(2)$ & 0.2 \\
\hline Cool & (37) & 3.7 & Whale & (6) & 0.6 & Mud flat experience & $(2)$ & 0.2 \\
\hline Fish & (32) & 3.2 & Navy & (6) & 0.6 & Good & $(2)$ & 0.2 \\
\hline Fishing & (32) & 3.2 & Swimming & (6) & 0.6 & Young & $(2)$ & 0.2 \\
\hline Ship & $(25)$ & 2.5 & Nature & $(5)$ & 0.5 & Horizon & $(2)$ & 0.2 \\
\hline Vacation & (23) & 2.3 & Memory & (5) & 0.5 & Light housekeeper & (2) & 0.2 \\
\hline Ship Seweol & $(23)$ & 2.3 & Dokdo Island & (5) & 0.5 & Marine sports & $(2)$ & 0.2 \\
\hline Seagull & (22) & 2.2 & Marine accident & (5) & 0.5 & Storm & (2) & 0.2 \\
\hline Wide & (21) & 2.1 & Busan & (5) & 0.5 & Ulleungdo Island & $(2)$ & 0.2 \\
\hline Clean & (18) & 1.8 & Fisherman & (5) & 0.5 & Relaxed & (2) & 0.2 \\
\hline Haeundae & $(17)$ & 1.7 & West Coast & (5) & 0.5 & Night sea of Yeosu & $(2)$ & 0.2 \\
\hline Sashimi & (17) & 1.7 & Romance & (5) & 0.5 & Pleasure boat & (2) & 0.2 \\
\hline Lighthouse & $(16)$ & 1.6 & Gyeongpodae Pavilion & (4) & 0.4 & Yacht & (2) & 0.2 \\
\hline Sunrise & $(16)$ & 1.6 & Clean sea area & (4) & 0.4 & Aquaculture & $(2)$ & 0.2 \\
\hline Water & $(15)$ & 1.5 & Diverse & (4) & 0.4 & Alcoholic beverages & $(2)$ & 0.2 \\
\hline $\begin{array}{c}\text { My chest is } \\
\text { open. }\end{array}$ & (14) & 1.4 & Foods & (4) & 0.4 & Suba diving & (2) & 0.2 \\
\hline Travel & (13) & 1.3 & Dabbling in water & (4) & 0.4 & Fresh & $(2)$ & 0.2 \\
\hline Jeju Island & (12) & 1.2 & Vacation & (4) & 0.4 & $\begin{array}{l}\text { The Old Man and } \\
\text { the Sea }\end{array}$ & (2) & 0.2 \\
\hline $\begin{array}{c}\text { Haenyeo } \\
\text { (female diver) }\end{array}$ & (11) & 1.1 & Abundant & (4) & 0.4 & Sunset & (2) & 0.2 \\
\hline Swimming & (11) & 1.1 & $\begin{array}{c}\text { There are plenty of } \\
\text { fisheries. }\end{array}$ & (4) & 0.4 & Typhoon & (2) & 0.2 \\
\hline Sand & (11) & 1.1 & Swimsuit & (4) & 0.4 & Tube & $(2)$ & 0.2 \\
\hline Comfortable & (11) & 1.1 & South Coast & (4) & 0.4 & Pacific Ocean & $(2)$ & 0.2 \\
\hline
\end{tabular}




\begin{tabular}{|c|c|c|c|c|c|c|c|c|}
\hline port & $(10)$ & 1.0 & Cruise travel & $(4)$ & 0.4 & Seashell & $(1)$ & 0.1 \\
\hline Mud flat & $(9)$ & 0.9 & Tourist destination & $(3)$ & 0.3 & Others & $(53)$ & 5.3 \\
\hline Summer & $(9)$ & 0.9 & Deep & $(3)$ & 0.3 & None & $(2)$ & 0.2 \\
\hline Island & $(9)$ & 0.9 & Jeongdongjin & $(3)$ & 0.3 & & & \\
\hline Dolphin & $(8)$ & 0.8 & Sailing boat & $(3)$ & 0.3 & & & \\
\hline Vacation spot & $(8)$ & 0.8 & Marine resource & $(3)$ & 0.3 & & & \\
\hline
\end{tabular}

\subsubsection{Familiarity with the Sea for Each Characteristic of Respondents}

As a result of asking how friendly you feel about the sea, $70.2 \%$ answered "friendly" (very friendly $10.1 \%+$ friendly $60.1 \%$ ).

Table 3: Familiarity with the Sea for Each Characteristic of Respondents

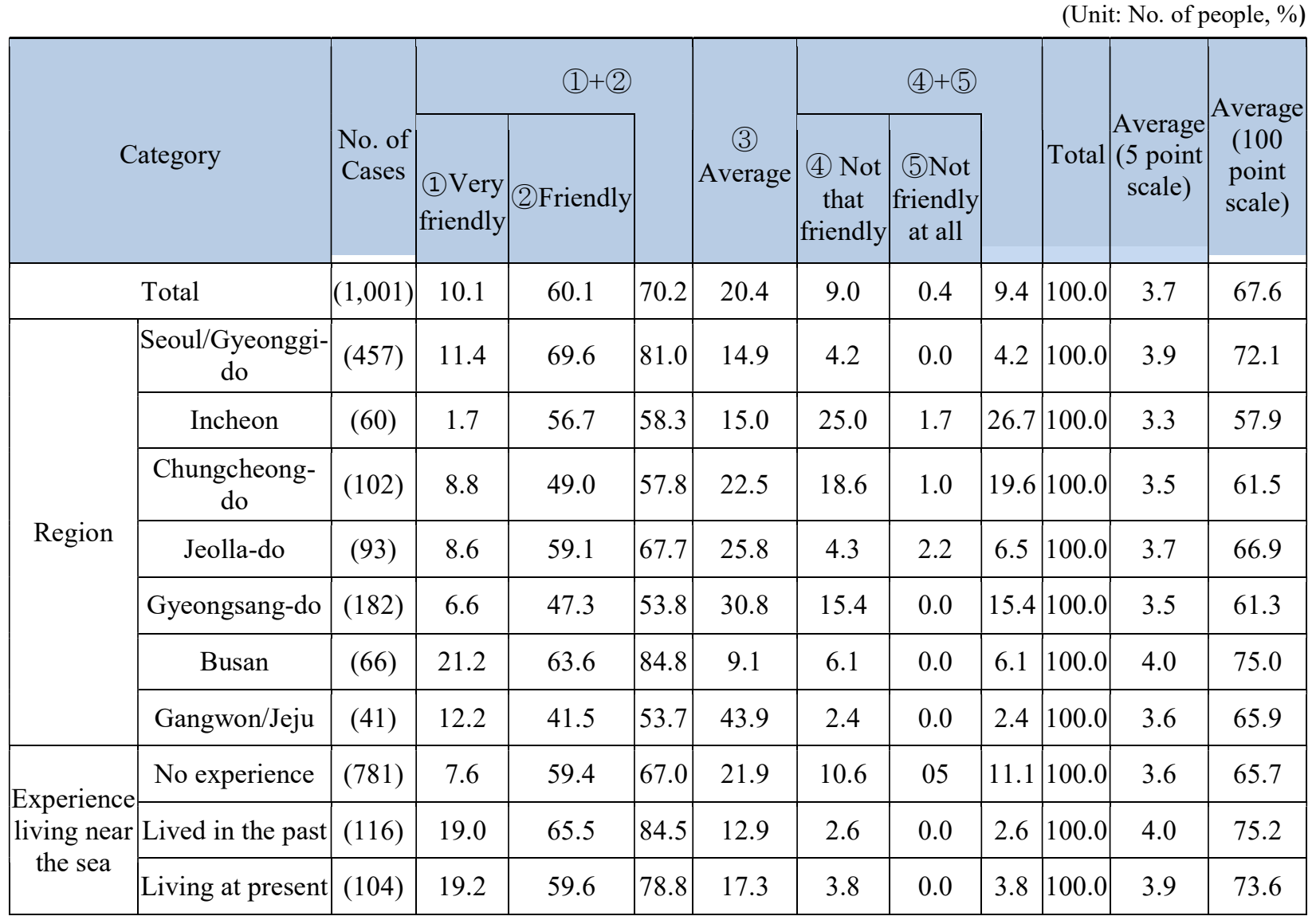

"Average" was 20.4\% (unit: \%, $\mathrm{n}=1,001$ ). 9.4\% said "not friendly". By region, respondents who answered "friendly" were relatively high in Seoul/Gyeonggi-do (81.0\%) and Busan $(84.8 \%)$. The higher the occupational relevance with the sea, the higher the familiarity and the higher familiarity with the past residents in the neighborhood of the sea.

\subsubsection{The Extent to which the Sea Affects Life}

As a result of questioning the extent to which the sea affects an individual's life, it was found that it had a relatively large effect on leisure/cultural life (average 70.4 points) and eating habits (average 75.7 points). On the 
other hand, the effect on household economy (average 47.8 points) and residential life (average 44.9 points) was relatively low. Finally, the individual's happiness was an average of 50.1 points.

\subsubsection{Ports Representing South Korea}

As a result of questioning about ports representing South Korea, $41.1 \%$ of respondents answered "Busan Port". Followed by Mokpo Port (21.8 percent) and Incheon Port (16.8 percent). Also, 53.6\% of the respondents answered "Jeju Island" in a result of asking about representative islands of Korea. Followed by Dokdo Island (13.3\%) and Ulleungdo Island (12.1\%).

Table 4: Ports Representing South Korea for Each Characteristic of Respondents

\begin{tabular}{|c|c|c||c|c|c|}
\hline Category & No. of Cases & $\%$ & Category & No. of Cases & $\%$ \\
\hline Total & $(1,001)$ & 100.0 & Daecheon Port & $(8)$ & 0.8 \\
\hline Busan Port & $(411)$ & 41.1 & Jeju Island & $(6)$ & 0.6 \\
\hline Mokpo Port & $(218)$ & 21.8 & Masan Port & $(6)$ & 0.6 \\
\hline Incheon Port & $(168)$ & 16.8 & Sorae Port & $(5)$ & 0.5 \\
\hline Sokcho Port & $(29)$ & 2.9 & Tongyoung Port & $(4)$ & 0.4 \\
\hline Others & $(23)$ & 2.3 & Samcheonpo Port & $(3)$ & 0.3 \\
\hline Pohang & $(20)$ & 2.0 & Guryongpo & $(3)$ & 0.3 \\
\hline Yeosu Port & $(18)$ & 1.8 & Cheongsapo Port & $(2)$ & 0.2 \\
\hline Jumoonjin Port & $(15)$ & 1.5 & Wando Island & $(2)$ & 0.2 \\
\hline Ulsan Port & $(13)$ & 1.3 & Plleungdo Island & $(2)$ & 0.2 \\
\hline Kunsan Port & $(11)$ & 1.1 & Daebudo Island & $(2)$ & 0.2 \\
\hline Daepo Port & $(11)$ & 1.1 & Yeongil Bay Port & $(2)$ & 0.2 \\
\hline Yeonan Pier & $(9)$ & 0.9 & Geojedo Port & $(2)$ & 0.2 \\
\hline Pyeongtaek Port & $(8)$ & 0.8 & & & \\
\hline
\end{tabular}

\subsubsection{South Korea's Representative Beaches}

When asked about the beaches representive of South Korea, $44.2 \%$ of respondents answered "Haeundae". Followed by Gyeongpodae (13.6\%) and Daecheon (8.4\%).

Table 5: Beaches Representing South Korea for Each Characteristic of Respondents

(Unit: No. of people, \%)

\begin{tabular}{|l|c|c||c|c|c|}
\hline \multicolumn{1}{|c|}{ Category } & No. of Cases & $\%$ & Category & No. of Cases & $\%$ \\
\hline Total & $(1,001)$ & 100.0 & $\begin{array}{c}\text { Wando Sinji } \\
\text { Myeongsasimni }\end{array}$ & $(7)$ & 0.7 \\
\hline Haeundae & $(442)$ & 44.2 & Songjeong & $(6)$ & 0.6 \\
\hline Gyeongpodae & $(136)$ & 13.6 & Byeonsan & $(5)$ & 0.5 \\
\hline
\end{tabular}




\begin{tabular}{|l|c|c||c|c|c|}
\hline Daecheon & $(84)$ & 8.4 & Dadaepo & $(5)$ & 0.5 \\
\hline Gwanganri & $(47)$ & 4.7 & Hamdeok & $(5)$ & 0.5 \\
\hline Manripo & $(27)$ & 2.7 & Busan & $(5)$ & 0.5 \\
\hline Ggokji & $(27)$ & 2.7 & Hyeopjae & $(5)$ & 0.5 \\
\hline Songdo & $(23)$ & 2.3 & East Sea & $(4)$ & 0.4 \\
\hline Sokcho & $(18)$ & 1.8 & Seonyudo Island & $(4)$ & 0.4 \\
\hline Gangneung & $(15)$ & 1.5 & Geojedo Island & $(4)$ & 0.4 \\
\hline Naksan & $(12)$ & 1.2 & Jeju Island & $(3)$ & 0.3 \\
\hline Mangsang & $(12)$ & 1.2 & Mongsanpo & $(3)$ & 0.3 \\
\hline $\begin{array}{l}\text { Anmyeondo } \\
\text { Island }\end{array}$ & $(11)$ & 1.1 & Homigot & $(3)$ & 0.3 \\
\hline Gyeongpo & $(10)$ & 1.0 & Pohang & $(3)$ & 0.3 \\
\hline Jumoonjin & $(8)$ & 0.8 & Mancheongri & $(3)$ & 0.3 \\
\hline Eurwangni & $(7)$ & 0.7 & Others & $(47)$ & 4.7 \\
\hline Mongdol & $(7)$ & 0.7 & Do not know/No & $(3)$ & 0.3 \\
\hline
\end{tabular}

\subsubsection{Emotions about the Sea}

When asked about whether they feel positive (or negative) emotion about the sea, $88.8 \%$ answered "feel good" when they see or think of the sea. "Average" was $11.0 \%$ and "feel bad" was $0.2 \%$ (Unit: $\%, n=1,001$ ). Respondents in Seoul, Gyeonggi, Incheon, and Busan regions showed a higher rate of "feel good" response.

As a result of questioning the degree of feeling about the sea by each emotion, the answer of "feel that way" about the positive emotion words such as "lively (71.1 points)" and "exciting (70.6 points)" are high. The 100-point average scores of negative emotional words such as "challenging (34.4.6 points)", "fearful (49.4 points)", "uneasy (54.9 points)", and "unfamiliar (59.6 points)" were calculated inversely.

\subsection{Marine (Sea) Familiarity Index}

Based on the survey of the previous marine (sea) awareness, this study derived the marine (sea) familiarity index in order to comprehensively identify the familiarity. The familiarity index, which indicates the degree of familiarity with the sea that combines the degree of familiarity with the sea, the degree of interest, the degree to which the sea affects the life and the positive emotions about the sea was 64.5 points. In detail, the friendliness/interest is 65.5 , the influence on my life is 60.0 , and the positive emotional induction is 68.8 (Unit: point, $\mathrm{n}=1,001$ ). It was shown that people living in Busan felt more friendliness than other regions (70.6 points). In the survey, respondents living in areas near the sea, such as Incheon and Busan, felt that the sea had a greater influence on their lives. Table: 6 describe the demographic characteristics of this study. Out of the total 1001 samples, 273 people aged $40-49$ were found to be relatively large. 
Table 6: Familiarity Index about the Sea for Each Characteristic of Respondents

(Unit: No. of people, point)

\begin{tabular}{|c|c|c|c|c|c|c|}
\hline \multicolumn{2}{|c|}{ Category } & No. of & Familiarity & $\begin{array}{l}\text { Friendliness / } \\
\text { Interest }\end{array}$ & Influence on & Positive Emotional \\
\hline \multicolumn{2}{|r|}{ Total } & $(1,001)$ & 64.5 & 65.5 & 60.0 & 68.0 \\
\hline \multirow{2}{*}{ Gender } & Male & (510) & 64.2 & 65.3 & 59.4 & 67.9 \\
\hline & Female & (491) & 64.8 & 65.8 & 60.6 & 68.1 \\
\hline \multirow{4}{*}{ Age } & $19 \sim 29$ & $(231)$ & 64.0 & 64.5 & 60.1 & 67.3 \\
\hline & $30 \sim 39$ & (231) & 64.6 & 66.3 & 59.5 & 68.0 \\
\hline & $40 \sim 49$ & $(273)$ & 64.0 & 64.7 & 59.6 & 67.8 \\
\hline & $50 \sim 59$ & $(266)$ & 65.4 & 66.6 & 60.8 & 68.7 \\
\hline \multirow{7}{*}{ Region } & Seoul/ & $(457)$ & 66.3 & 68.4 & 61.9 & 68.6 \\
\hline & Incheon & (60) & 65.8 & 62.3 & 67.6 & 67.5 \\
\hline & Chungcheong-do & (102) & 60.6 & 61.9 & 53.1 & 66.8 \\
\hline & Jella-do & (93) & 60.9 & 64.0 & 52.4 & 66.4 \\
\hline & Gyeongsang-do & $(182)$ & 62.7 & 60.7 & 60.6 & 66.9 \\
\hline & Busan & (66) & 70.6 & 72.0 & 66.5 & 73.2 \\
\hline & Gangwon/Jeju & (41) & 58.1 & 61.0 & 48.9 & 64.5 \\
\hline
\end{tabular}

\section{Conclusion}

National image is formed by normative, cognitive, and emotional factors. It can also be formed by a textual path, a relational path, or a personal experience path. National image affects the product image, and its ripple effect such as tourism image is very high. Therefore, in order to improve national image, various efforts are needed through various routes. Especially, familiarity is formed highly according to consumers' cognitive, emotional, relationship and personal experiences. This familiarity can contribute greatly to the improvement of national image.

In this study, this study has identified the actual situation to improve national image through familiarity with the sea. In particular, this study could see how much familiar emotion to the sea people have by identifying it with quantitative index. As mentioned at the introduction, South Korea, whose three sides are surrounded by the sea, 
needs to develop and utilize in-kind assets and services in order to utilize more sea resources. Familiarity with the sea can be an important asset in creating more tourism revenue, local development and attractiveness.

Through the analysis of the realities of the awareness about free association about the sea, the degree of familiarity with the sea, the relationship between the sea and life, the interest in the sea, the marine regions representative of South Korea, and the emotionality related to the sea, it was found that the sea influences the life of culture of Korean people a lot. This study has implications for the understanding of the fields that require policy attention and effort through this identification of the detailed actual situation.

Also, practically existing studies on the sea have been mainly focused on the perspective of tourism, marine ecology and engineering, with particular focus on logistics and transportation. Therefore, this study on the perspective of the formation of national image suggests a new approach to add and utilize new variables to future research using the sea and ocean.

In conclusion, academically this study has identified the marine tourism resources, marine ecology, and the cognitive and emotional situations consumers feel that should be developed practically. If a continuous time series research is conducted in the future through these, it will be a chance to provide a basis for consumers' dynamic awareness.

On the other hand, the limitations of this study are lack of systematic modeling and empirical analysis for empirical studies due to the lack of existing empirical studies. In addition, this study expects that comparative studies will be carried out in the future to compare foreign consumers with domestic consumers in using samples.

\section{References}

Ahn, J. S. (2005). Multifaceted country image and its impact on product evaluation and brand attitude: a case for Chinese consumers. International Business Journal, 16(2), 63-90.

Bae, I. H., Kim H. S. (2011). A Korean wave diffusion strategy through success of culture contents in Thailand. Journal of Product Research, 29(5), 21-32.

Chang, Y. I. (2013). The effects of country image of services on Chinese consumer's quality perception, attitude and purchase intention. The Journal of International Trade \& Commerce, 9(1), 515-54.

Choi, J. W. (2013). A study on implications and activation strategy of case analysis on cultural marketing through the Korean wave. The Journal of International Trade \& Commerce, 9(7), 673-695

Ha, K. H. (2018). Study on marine culture tourism resources to promote marine tourism: focused on marine culture festival. Journal of Marine Tourism Research, 11(1), 9-25.

Hyun, M., Rui, D., G., Lee, C. S. (2019). A study on maritime situation through marine culture index and Korean wave synergy. Journal of Korea Research Association of International Commerce, 19(1), 47-68.

Ji, S. H. (2018). A Study on revitalization scheme of port redevelopment project. (Pusan, Korea: Thesis for Master in Pukyung National University University).

Kim, C. S. (2018). A study on the roles of Korea ocean business corporation to promote cooperation between shipping companies and shippers. Journal of International Trade \& Commerce, 14(5), 669-682.

Kim, E. J., Kim, M. J. Lee, J. H. (2018). A study on marine pollution management and export of ballast water. The Journal of International Trade \& Commerce, 14(5), 653-668.

Kim, G., Kim, H. C., Kim, J. H. (2014). Activation of ocean tourism considering: the characteristic of proposed. Journal of Tourism and Leisure Research 26(2), 67-81.

Kim, M. S., Rui, D. G., Lee, C. S. (2018). A study on the relationship between national image and marine friendliness, Korea Research Association of International Commerce, Article for the Spring Conference

Lee, B. B., Kang B. G. (2017). Development of Busan marine tourism contents using storytelling - focusing on the development of marine leisure theme course in Galmaetgil. The Journal of the Korea Contents Association, 17(8), 196-208.

Lee, C. S. (2006). An empirical study on the two-way effects between country image and corporate image: with emphasis on the Chinese consumer of Samsung electronics Co., LTD. (Seoul, Korea: Thesis for Doctorate in KOREA University). 
Lee, D., Ganesh, G. (1999). Effects of partitioned country image in the context of brand image and familiarity. International Marketing Review, 16(1), 18-39.

Lee, J. R., Lee, C. S. Yang, S. Y. (2009). An exploratory empirical study on determinants of Korea images: with governance, firms, individual activities variables. Korean Journal of Business Administration, 22(3), 5831601.

Lee, Y. K. (2015). The impact of fit between country and product image of Korea on the purchase intention. Journal of Korea Research Association, 15(4), 417-437.

Martin, I. M., Eroglu, S. (1993). Measuring a multi-dimensional construct: country image. Journal of Business Research, 28(1), 191-210.

Parameswaran, R., Pisharodi, R. M. (1994). Facts of country of origin image: an empirical assessment. Journal of Advertising, 23(1), 43-56.

Roth, M. S., Romeo, J. B. (1992). Matching product category and country image perception. Journal of International Business Studies, 47-497.

Yi, H. T., Lee, H. K. (2014). The effect of multifaceted country image on country-product image and brand evaluation. The Journal of International Trade \& Commerce, 10(3), 495-516.

Zhang, X. Kim, B. I., Lee, C. S. (2015). Influence of Korea's cultural products and country image on Chinese consumers' visiting intention of medical tour to Korea. Journal of Korea Research Association of International Commerce, 15(4), 1-21. 